Олена СТЕПАНЕНКО,

orcid.org/0000-0003-0887-5808

кандидат філологічних наук, доцент, докторант кафедри методики викладання світової літератури Національного педагогічного університету імені М. П. Драгоманова

(Київ, Украӥна) olena.step@ukr.net

\title{
РОЗВИТОК ВЕРБАЛЬНОЇ ТА НЕВЕРБАЛЬНОЇ КОМПЕТЕНТНОСТЕЙ УЧНІВ ЗАСОБАМИ ТРЕНІНГОВИХ ТЕХНОЛОГІЙ НА УРОКАХ ЗАРУБІЖНОЇ ЛІТЕРАТУРИ
}

\begin{abstract}
Сучасні умови суспільного розвитку все більше вимагають активного впровадження інноваційних технологій навчання, переосмислення усталених систем щзодо прийомів і методів у галузі освіти. В сучасному соціальноекономічному середовищі вчитель зарубіжної літератури має постійно вдосконалювати свій рівень знань, його педагогічний успіх залежить від результативності запровадження інновачійних технологій навчання, які грунтуються на нових методологічних засадах, сучасних дидактичних принципах і психолого-педагогічних теоріях, які розвивають компетентісний підхід до навчання.

Стаття присвячена одній з актуальних проблем у галузі інноваційних технологій навчання - тренінгу як інтерактивному засобу розвитку вербальної та невербальної компетентностей на уроках зарубіжної літератури. Серед основних аспектів дослідження варто зазначити пошук нових завдань сучасної освіти, вирішення проблем педагогічної інноватики, серед яких актуальним засобом є тренінг, щзо передбачає нестандартність навчального прочесу, у якому вчитель виконує роль тренера, а учні-учасників тренінгової групи.

Проблема системи методів і прийомів сучасного освітнього процесу зумовлена швидким розвитком інноваційної сфери навчального прочесу, інтерактивних засобів, які удосконалюють вміння та навички учасників изього прочесу. Методика використання тренінгу, яка здебільшого характерна для психологічної галузі, ефективно впроваджується в освітній сфері як на уроках у школі, так і під час занять в університеті. Оскільки основним атрибутом тренінгового заняття є взаємодія всіх учасників, ше зумовлюється специфікою методів та умов, нині тренінг є незамінним елементом системи навчання й розвитку в будь-якому навчальному закладi.

Тренінг - цее форма соціально-педагогічної діяльності, спрямована на набуття життєвої компетентності шляхом збагачення як знаннями, так і життєво-практичним та емочійно-особистісним досвідом завдяки використанню інтерактивних засобів навчання. Перевагами тренінгу є нестандартність форм проведення, він не схожий на класичні уроки, оскільки головним завданням тренінгу є встановлення контакту між учасниками групи та керівником (учителем).
\end{abstract}

Ключові слова: сучасна освіта, тренінг, інновачійні методи, інтерактивна технологія, мотивачія, тренінгова група, прийом експерименту.

\author{
OLena STEPANENKO, \\ orcid.org/0000-0003-0887-5808 \\ Candidate of Philological Sciences, Associate Professor, \\ Doctoral Candidate at the Department of Methods of Teaching World Literature \\ National Pedagogical Dragomanov University \\ (Kyiv, Ukraine) olena.step@ukr.net
}

\section{DEVELOPMENT OF VERBAL AND NON-VERBAL COMPETENCIES OF STUDENTS BY MEANS OF TRAINING TECHNOLOGIES IN LESSONS OF FOREIGN LITERATURE}

Current conditions of social development are increasingly demanding active introduction of innovative training technologies, redefining the established systems regarding techniques and methods in the field of education. In today's socio-economic environment, the teacher should constantly increase and improve his level of knowledge, his pedagogical success depends on the effectiveness of introducing innovative learning technologies, that are based on new methodological foundations, modern didactic principles, psychological and pedagogical theories that develop competent approach to learning.

The article is dedicated to one of the current problems in the field of innovative learning technologies - training as an interactive tool for the development of verbal and nonverbal competencies in foreign literature lessons. In particular, among the main aspects research is the finding new problems of modern education, solving problems pedagogical innovations, among which a topical tool is training that provides for the non-standard educational process in which the teacher performs the role of the trainer, and the students - the participants of the training group. 
The problem of the system of methods and techniques of the modern educational process is caused by the rapid development of the innovative sphere of the educational process, interactive tools that improve the skills of participants of this process. The method of using training, which is mainly representative in the psychological field, is effectively implemented in the educational field, both in the classroom and at school. As the main attribute of a training session is the interaction of all participants, which is conditioned by the specificity of methods and conditions, training today is an indispensable element of the system of learning and development in any educational institution.

Training is a form of socio-pedagogical activity aimed at gaining vital competence through the enrichment of both knowledge and vital, practical, emotional and personal experience through the use of interactive learning tools. The advantages of the training are the non-standard forms of conducting, it is not like the classical lessons, because its main task is to establish contact between the group members and the head (teacher).

Key words: modern education, training, innovative methods, interactive technology, motivation, training group, experiment reception.

Постановка проблеми. Сучасні умови суспільного розвитку все більше вимагають активного впровадження інноваційних технологій навчання, переосмислення усталених систем щодо прийомів і методів у галузі освіти. В сучасному вимогливому та швидкозмінному соціальноекономічному середовищі вчитель має постійно вдосконалювати свій рівень знань, його педагогічний успіх залежить від результативності запровадження інноваційних технологій навчання, які грунтуються на нових методологічних засадах, сучасних дидактичних принципах і психологопедагогічних теоріях, що розвивають компетентісний підхід до навчання (Оніщенко, 2015: 107).

Проєктуючи сучасну школу як модель суспільства, в центрі будь-якої діяльності має бути особистість, індивідуум, залишаючись при цьому активним учасником і посередником у взаємодії всіх суб'єктів навчання. Створення умов для появи і розвитку навчального та життєвого досвіду учня в плані функціональної предметної грамотності передбачає саме компетентісний підхід. Його метою $є$ створення умов для розвитку особистості учня в аспекті предметної функціональної грамотності. Тому інноваційні методи навчання $\epsilon$ поштовхом до розвитку та вдосконалення професійних компетенцій.

Метод - ключовий інструмент будь-якої діяльності, за допомогою якого здійснюється взаємодія під час навчання. Від правильно підібраної системи методів залежить рівень досягнення результату. Як зазначає Н. Софій, нові завдання сучасної освіти вимагають від педагога виконання багатьох різних ролей: розробник навчальних програм, фасилітатор, презентатор, тренер, наставник, менеджер, консультант, дослідник, агент змін (Софій, 2007).

Аналіз досліджень. Дослідники проблем педагогічної інноватики (О. Арламов, М. Бургін, В. Журавльов, В. Загвязинський, А. Ніколс та інші) намагаються співвіднести поняття «нового» в педагогіці 3 такими характеристиками як «корисне», «прогресивне», «позитивне», «сучасне», «передове». Таким сучасним іннова- ційним засобом розвитку вербальної та невербальної компетентностей на уроках зарубіжної літератури є тренінг, на якому вчитель виконує роль тренера, а учні - учасників тренінгової групи.

У корекційно-педагогічній роботі Р. Баклі та Дж. Кейпл визначають тренінг як сплановані та систематичні зусилля щодо модифікації чи розвитку знань, умінь, установок людини засобами навчання, завдяки яким можна досягнути ефективного виконання одного чи кількох видів діяльності. С. І. Макшанов розуміє поняття «тренінг» як «спосіб перепрограмування наявної в людини моделі управління своєю поведінкою і діяльністю». А. П. Ситніков розглядає тренінги як навчальні ігри, які поєднують у собі навчальну та ігрову діяльність. За Т. Зайцевою тренінг $є$ суб'єктивною методикою в конкретних процедуpax, засобом впливу на особистість, спрямованим на створення умов для ії цілеспрямованих змін.

Проблема системи методів і прийомів сучасного освітнього процесу зумовлена швидким розвитком інноваційної сфери навчального процесу, інтерактивних засобів, які удосконалюють вміння та навички учасників цього процесу. Методика використання тренінгу, яка здебільшого характерна для психологічної галузі, ефективно впроваджується в освітній сфері як на уроках у школі, так і під час занять в університеті. Оскільки основним атрибутом тренінгового заняття $є$ взаємодія всіх учасників, що зумовлюється специфікою методів та умов, то нині тренінг $є$ незамінним елементом системи навчання й розвитку в будь-якому навчальному закладі. Саме це й зумовило вибір теми статті.

Мета статті - визначити специфічні особливості тренінгу як інноваційного засобу сучасної освіти, проаналізувати основні атрибути тренінгу як неформального методу вирішення будь-якої проблеми та засобу розвитку вербальної та невербальної компетентностей на уроках зарубіжної літератури, спроєктувати всі переваги тренінгових занять на уроках, які лише розширюють спектр навчального процесу. Основними завданнями 
для досягнення мети $є$ аналіз історії розвитку та виникнення тренінгу, визначення інноваційних методів навчання з метою удосконалення професійних компетенцій, порівняння ключових аспектів тренінгу та традиційних методів навчання, дослідження застосування інтерактивних технологій, зокрема методів ігрового навчання, аналіз методики використання тренінгів.

Виклад основного матеріалу. Перевагами тренінгу $\epsilon$ нестандартність форм проведення. Він не схожий на класичні уроки, оскільки головним завданням тренінгу $є$ встановлення контакту між учасниками групи та керівником (учителем). На перший погляд тренінг має схожу структуру зі звичайним (класичним) уроком, в якому $є$ чітко окреслена тема, встановлена мета та засоби чи прийоми для iї досягнення. Проте тренінг передбачає більш ігровий підтекст, який здебільшого базується на практиці, теоретична ж його частина відходить на другий план.

Однією 3 форм тренінгового заняття може бути рольова гра, яка передбачає неформальне вирішення конкретної проблеми за допомогою моделювання реальних життєвих ситуацій, удосконалення емпатичних навичок (співпереживання) та спроби «бути собою», долаючи всі психологічні бар'єри. Головним атрибутом такого методу є прийом експерименту, перевагами якого $\epsilon$ вироблення навичок аналізу проблемних ситуацій, критичного і творчого мислення. Для тренінгу характерна активність всіх учасників, спрямованість навчального процесу в ігровому аспекті та створення творчої атмосфери з метою розвитку та вдосконалення вмінь і навичок у межах колективу, групи.

Необхідно зазначити, що дослідницькі роботи, творчі виступи, театральні вистави, музичні концерти, наукові проєкти порівняно 3 тренінгом втрачають свою актуальність, оскільки саме тренінг передбачає низку активних та інтерактивних методів навчання, які 3 кожним днем стають все більш популярними в будь-якій освітній сфері. Тренінг як навчальний засіб входить до складу групи активних методів навчання, є альтернативою пасивним методам.

Тренінг як інноваційна форма навчання сформувався на початку ХХ ст. У 1950-1970 pp. тренінг розвивався як форма соціально-психологічної здібності особистості взаємодіяти з оточуючими людьми. Нині тренінг широко застосовується, вийшовши за рамки практичної психології та підготовки фахівців (Безпалько, 2004: 15).

В основі тренінгу як особливого неформального способу вирішення будь-якої проблеми лежить процес комунікації в межах конкретної групи. Методи та засоби під час тренінгу не обмежують учасників, а створюють сприятливу атмосферу, яка стимулює взаємодію всіх учасників групи для вирішення проблемного питання. Їх ще можна назвати «інтерактивними», оскільки під час будь-якого тренінгу незалежно від його форми та тривалості між учасниками відбувається активний процес навчання.

Урізноманітнення методів і засобів під час тренінгу розширює спектр навчального процесу, охоплюючи як теоретичну, так і практичну базу заняття, але при цьому необхідно враховувати рівень обізнаності учасників 3 конкретної теми, ресурси та умови проведення такого інтерактивного заняття. Особливістю такого навчального процесу $є$ взаємодія як між учасниками групи, так і з тренером (учителем), оскільки тренінг передбачає впровадження нових підходів, засвоєння та обробку нової інформації, розвиток нових вмінь і навичок з метою самовдосконалення.

Тренінг - це форма соціально-педагогічної діяльності, спрямована на набуття життєвої компетентності шляхом збагачення як знаннями, так і життєво-практичним та емоційно-особистісним досвідом завдяки використанню інтерактивних засобів навчання (Бопко, 2015). Тренінг одночасно $є$ не лише цікавим процесом пізнання себе та інших під час спілкування, а й інструментом для формування нових вмінь і навичок.

Тренінг має свої «атрибути»: тренінгова група, тренінгове коло, спеціальне обладнання для роботи, тренер, правила групи, атмосфера взаємодії та спілкування, інтерактивні методи навчання, структура тренінгового заняття, оцінювання ефективності тренінгу (Бевз, 2005). Тренінг і традиційні форми навчання мають суттєві відмінності. Традиційне навчання більш орієнтоване на правильну відповідь і за своєю суттю $є$ формою передачі інформації та засвоєння знань. Тренінг насамперед орієнтований на запитання та пошук. На відміну від традиційних, тренінгові форми навчання повністю охоплюють весь потенціал: рівень та обсяг компетентності особистості (соціальної, емоційної та інтелектуальної), самостійність, здатність до прийняття рішень, до взаємодії (Бевз, 2005).

Як і будь-яке навчальне заняття, тренінг має певну мету: інформування та набуття учасниками тренінгу нових професійних навичок і вмінь; опанування нових технологій у професійній сфері; зміна погляду на проблему; зміна погляду на процес навчання (Безпалько, 2004: 23). Нині тренінг став найпоширенішою інтерактивної технологією серед методів ігрового навчання, предметом 
яких є професійні контакти. Велику ефективність у підготовці фахівців в сфері педагогіки мають комунікативні тренінги 3 розвитку вербальної та невербальної компетентності учнів, їхніх інтерактивних вмінь і навичок. Організація процесу спілкування в такому тренінгу, тобто навчання діяльністю, і є головним засобом здійснення корекційних впливів.

Необхідно застосовувати зміну стилю і темпу ведення тренінгу для того, щоб пристосовуватися до різного типу слухачів та їхньої модальності, різних типів інтелекту, досвіду. Для урізноманітнення навчання варто використовувати кольорове і музичне оформлення, робити навчання схожим на гру (Федорчук, 2014: 150).

Для отримання нової інформації під час навчання необхідним складником є мотивація. Мотивація - своєрідний комплекс мотивів, який спонукає людину до конкретних форм діяльності або поведінки. Потреби, інтереси, захоплення, емоції, ідеали здебільшого є мотивами. Проте в одних випадках інтерес базується на досягненні кращого результату (оцінки), а в інших - інтересу до самого процесу навчання (змісті). Тому особливістю тренінгу є неформальне, невимушене спілкування учасників тренінгу, яке відкриває групі безліч варіантів розв'язання проблеми та лише підсилює мотивацію у навчанні.

У тренінгу широко використовуються методи, спрямовані на стимуляцію взаємодії учасників. Переваги групової роботи полягають у тому, що 3 інформацією та досвідом можуть ознайомитися всі члени групи. Крім того, існує можливість легко давати інструкції відразу всім учасникам. Набуття нових навичок і досвіду під час тренінгу відбувається завдяки активній участі всіх членів групи та кожного з них окремо (Красовицький, Бєлкіна, 2002: 12).

Відомі розробники теорії і практики тренінгу Ю. Н. Смельянов та Е. С. Кузьмін поєднують активні групові методи у три загальні блоки:
1) дискусійні методи (групова дискусія, аналіз випадків із практики, аналіз ситуацій морального вибору, моделювання практичних ситуацій, метод кейсів);

2) ігрові методи: а) дидактичні, імітаційні і творчі ігри, в тому числі ділові; б) рольові ігри (інтонаційно-мовний, відеотренінг, ігрова психотерапія, психодраматична корекція); в) мозковий штурм; г) контргра (трансактний метод усвідомлення комунікативної поведінки);

3) сенсетивний тренінг (тренування самопізнання (усвідомлення), міжособистісної чуттєвості та емпатіi) (Красовицький, Бєлкіна, 2002: 12).

Окрім методів (методик), які використовують у тренінгах, фахівці вибирають види тренінгів залежно від учасників, тематики і рівня складності проблем організації (індивідуальний, системний, стратегічний) (Ковальчук, 2005: 340).

Висновки. Отже, тренінг - це одночасно практичний та ефективний метод опанування новими знаннями з зарубіжної літератури; процес взаємодії між учасниками та тренером; навчання, яке стимулює та активізує інтерес до пізнання; можливість відкриття нових вмінь і навичок; продуктивна форма розширення власного набутого досвіду; нестандартна форма соціально-педагогічної діяльності, спрямована на набуття життєвої компетентності шляхом збагачення та самовдосконалення як теоретично, так і практично завдяки використанню інтерактивних засобів навчання зарубіжної літератури.

Тренінг, на думку фахівців, подібний до самого життя в мініатюрі. Часто вживається вислів: «Тренінг - це гра в життя, під час якої вирішуються реальні життєві проблеми». Оволодіння новими технологіями навчання й виховання вимагає внутрішньої готовності вчителя до розуміння необхідності освіти протягом всього життя, серйозної діяльності щодо запровадження нових методів навчання та викладання, адаптації до нових умов розвитку суспільства (Оніщенко, 2015: 107).

\section{СПИСОК ВИКОРИСТАНИХ ДЖЕРЕЛ:}

1. Бевз Г. М. Основні положення щодо проведення тренінгів. URL: http://ru.osvita.ua/school/method/technol/598/ (дата звернення: 18.11.2020).

2. Безпалько О. В. Тренінг як інноваційна форма соціально-педагогічної роботи. Соціальна педагогіка: теорія та практика. 2004. № 1. С. 22-28.

3. Бопко I. 3. Роль інноваційних технологій у формуванні педагогічної техніки майбутніх вчителів іноземних мов. Вісник Національної академії Державної прикордонної служби України. 2015. Вип. 2. URL: http://C:/Users/pc1/ Downloads/Vnadps_2015_2.pdf (дата звернення: 17.11.2020).

4. Брусєнцева О. А. Впровадження інноваційних педагогічних технологій як складник розвитку вищої освіти в сучасних умовах. Теорія та методика управління освітою. 2010. № 4. URL: (дата звернення: 19.11.2020).

5. Красовицький М., Бєлкіна О. Сучасні уроки (інноваційні технології: тренінги, інтерактивні форми навчання, критичне мислення). Завуч. 2002. № 35. С. 12.

6. Макшанов С. И. Психология тренинга: Теория. Методология. Практика : монография. URL: https://studfile.net/ preview/3584098/ (дата звернення: 19.11.2020). 
7. Оніщенко О. В. Тренінг як інноваційна методика навчання в системі післядипломної педагогічної освіти. Вісник Чернігівського національного педагогічного університету. Серія: Педагогічні науки. 2015. Вип. 132. С. $106-109$. URL: http://visnyk.chnp.edu.ua/dl/2416 (дата звернення: 17.11.2020).

8. Софій Н. Інноваційні методи навчання та викладання. URL: http://osvita.ua/school/method/1663 (дата звернення: 18.11.2020).

9. Тренінгові технології навчання з економічних дисциплін. Навчальний посібник / за заг. редакцією Г. О. Ковальчук. Київ : КНЕУ, 2005. 377 с.

10. Федорчук В. М. Тренінг особистісного зростання : навчальний посібник. Київ : Центр учбової літератури, 2014. 250 c. URL: http://www.posek.km.ua/images/stories/doc/trening_osobystogo_zrostannay.pdf (дата звернення: 19.11.2020).

\section{REFERENCES}

1. Bevz H. M. Osnovni polozhennia shchodo provedennia treninhiv [Basic provisions for training]. URL: http://ru.osvita.ua/school/method/technol/598/ [in Ukranian] (accessed: 18 November 2020).

2. Bezpalko O. V. Treninh yak innovatsiina forma sotsialno-pedahohichnoi roboty [Training as an innovative form of socio-pedagogical work]. Sotsialna pedahohika: teoriia ta praktyka. 2004. № 1. S. 22-28 [in Ukranian].

3. Bopko I. Z. Rol innovatsiinykh tekhnolohii u formuvanni pedahohichnoi tekhniky maibutnikh uchyteliv inozemnykh mov [The role of innovative technologies in the formation of pedagogical techniques of future teachers of foreign languages]. Visnyk Natsionalnoi akademii Derzhavnoi prykordonnoi sluzhby Ukrainy. 2015. Vyp. 2. URL: http://C:/Users/pc1/Downloads/Vnadps_2015_2_7.pdf [in Ukranian] (accessed: 17 November 2020).

4. Brusientseva O. A. Vprovadzhennia innovatsiinykh pedahohichnykh tekhnolohii yak skladova rozvytku vyshchoi osvity v suchasnykh umovakh [Introduction of innovative pedagogical technologies as a component of higher education development in modern conditions]. Teoriia ta metodyka upravlinnia osvitoiu. 2010. № 4. URL: http://tme.umo.edu.ua/ docs/4/10bruemt.pdf [in Ukranian] (accessed: 19 November 2020).

5. Krasovytskyi M., Bielkina O. Suchasni uroky (innovatsiini tekhnolohii: treninhy, interaktyvni formy navchannia, krytychne myslennia) [Modern lessons (innovative technologies: trainings, interactive forms of learning, critical thinking)]. Zavuch. 2002. № 35. S. 12 [in Ukranian].

6. Makshanov S. Y. Psykholohyia trenynha: Teoryia. Metodolohyia. Praktyka : monohrafyia [Training psychology: Theory. Methodology. Practice : monograph]. URL: https://studfile.net/preview/3584098/ [in Ukranian] (accessed: 19 November 2020).

7. Onishchenko O. V. Treninh yak innovatsiina metodyka navchannia v systemi pisliadyplomnoi pedahohichnoi osvity [Training as an innovative teaching method in the system of postgraduate pedagogical education]. Visnyk Chernihivskoho natsionalnoho pedahohichnoho universytetu. Seriia: Pedahohichni nauky. 2015. Vyp. 132. S. 106-109. URL: http://visnyk.chnp.edu.ua/dl/2416 [in Ukranian] (accessed: 25 November 2020).

8. Sofii N. Innovatsiini metody navchannia ta vykladannia [in Ukranian]. URL: http://osvita.ua/school/method/1663 [Innovative teaching and learning methods] (accessed: 18 November 2020).

9. Treninhovi tekhnolohii navchannia z ekonomichnykh dystsyplin. Navchalnyi posibnyk [Training technologies of training in economic disciplines] / za zah. redaktsiieiu H. O. Kovalchuk. Kyiv : KNEU, 2005. 377 s. [in Ukranian].

10. Fedorchuk V. M. Treninh osobystisnoho zrostannia : navchalnyi posibnyk [Personal growth training : a textbook]. Kyiv : Tsentr uchbovoi literatury, 2014. 250 s. URL: http://www.posek.km.ua/images/stories/doc/trening_osobystogo_ zrostannay.pdf [in Ukranian] (accessed: 19 November 2020). 